\title{
Sarticulos
}

\section{La Flor del Carmelo. Iconografía y mensaje simbólico de la iglesia conventual del Carmen de Antequera (I)}

\author{
María José Carmona Mato \\ Investigadora vinculada a la Universidad de Málaga
}

RESUMEN

La Iglesia del Carmen de Antequera es uno de los más sobresalientes exponentes de la arquitectura y artes plásticas del Barroco andaluz. Construida entre los siglos XVI-XVIII, el edificio constituye un ejemplo paradigmático de espacio parlante dedicado a la exaltación de la Orden del Carmelo, a través de las figuras de los grandes santos carmelitas, santos y santas que se integran en el mistico "cielo" que rodea a la Virgen del Carmen, en un discurso iconográfico apologético resuelto en clave triunfal. El presente trabajo estudia, publicado en dos partes, tan exhaustivo ciclo.

PALABRAS CLAVE: Iconografía/ Arquitectura/ Órdenes Religiosas/ Barroco/ Andalucía

Flower of Mount Carmel. Iconography and Symbolical Meaning of "Carmen" Church in Antequera (I)

ABSTRACT

The Church of Our Holy Mother of "El Carmen" in Antequera (town located in the province of Málaga, Spain) was built between XVI-XVIII centuries. The temple is considered one of the greatest examples of the Baroque Art in Andalusia. Their architecture and altarpieces are a praising of the Carmelite Order through magnificent Carmelite figures, saints who integrate in the mistic sky surrounding the Virgin of "El Carmen". Our article studies, divided in two parts, this interesting iconographical cycle. Andalusia

KEY WORDS: Iconography/ Architecture/ Religious Orders/ Baroque/

Aunque en un primer momento, la cantidad de imágenes que pueblan esta iglesia puede llegar a confundirnos o abrumarnos, pronto advertimos que nos hallamos en un templo carmelitano. Esto se debe a que, ciertamente, son las imágenes de la Virgen del Carmen y de San Elías las que ocupan los lugares más destacados del retablo central, las demás figuras están en función de ellas. Por tanto, serán dos los temas que principalmente se van a desarrollar: el "mariano" y el "eliano". Pero si pretendemos captar el mensaje que la totalidad de la iconografía nos quiere transmitir, será preciso que tratemos por separado y detalladamente cada una de estas dos líneas temáticas. Esto nos permitirá el poder emitir más adelante una más acertada y armónica visión de conjunto.

* CARMONA MATO, Ma José: "La Flor del Carmelo. Iconografía y mensaje simbólico de la iglesia conventual del Carmen de Antequera (I)", en Boletín de Arte, n²9, Departamento de Historia del Arte, Universidad de Málaga, 2008, págs. 135-157. 


\section{Q: artículos María José Carmona Mato}

Sobrecoge el retablo central de la capilla mayor. Es, sin duda, la pieza más sobresaliente de la iglesia dada la particular belleza del mismo. Pero, no hay que olvidar que éste no es sino el marco del Camarín, que a su vez está en función de la imagen de la Virgen del Carmen. En este punto comienza (o más bien concluye, como veremos) la directriz mariana.

\section{LÍNEA MARIANA. \\ El camarín de la Virgen del Carmen.}

El sentido del camarín, espacio totalmente independiente y delimitado en sí mismo, es el apartar a la imagen de los fieles y rodearla de un halo de misterio. Se la hace inaccesible, es cierto, pero al mismo tiempo al ser tratada de forma diferente al resto de las imágenes se la resalta sobremanera entre todas ellas. Este camarín, inusual entre los antequeranos por su planta mixtilínea, y entre los barrocos por sus modestas yeserías ornamentales destaca, sin embargo, por su colorista decoración pictórica. La planta se divide en seis lóbulos que se continúan en altura dando forma a los paramentos de la pared y a los plementos de la cúpula. En cada uno de estos espacios encontramos inscripciones apoyadas por dibujos que hacen referencia a las letanías marianas. En los plementos de la cúpula de derecha a izquierda tenemos: una estrella y la inscripción "Matutina", un cáliz y "Espiritual", un templo y "Aúrea", una puerta y "Caeli" un espejo y "Justicia". En el lugar de intersección entre la cúpula y los lóbulos de la pared observamos los dibujos de una fuente, un sol, el escudo de la Orden, una cara de luna, un pozo y una fortaleza. Ya en la pared de izquierda a derecha tenemos: en la parte superior del primer lóbulo el dibujo de una rosa y escrita la palabra "Mística", debajo se sitúa la puerta; en el segundo se abre una ventana; en la parte superior del tercero "Honorabili" junto a un copón, en la inferior "Federis" y un arca con una paloma; en el cuarto en la parte superior "Insigne devotiones" junto a un jarrón, en la inferior "Eburnea" con una fortaleza. En el quinto una ventana y en el sexto la inscripción "Quasi palma" acompañada de una palmera y "quasi cyprefsus" de un ciprés. Toda esta policromía rodea la figura de la Virgen, que se sitúa dentro de un trono-templete de brazos convergentes. Dicha figura es una imagen de vestir típica de la iconografía carmelitana, que se viste con el hábito marrón, la capa blanca y cubre su cabeza con mantilla blanca y corona de plata. En su brazo izquierdo, en cuya mano lleva un cetro, porta al niño, mientras con la mano derecha sostiene el escapulario. Conviene señalar que la tradición afirma que el tipo iconográfico de María con el niño es traído a occidente desde el Monte Carmelo ${ }^{1}$.

El padre Saggi ${ }^{2}$ afirma que María fue venerada por los carmelitas en el trans-

1, L. (O. Carm.): "Santa María del Monte Carmelo" en SAGGI, L (Coord).: Santos del Carmelo, Madrid, Ed. de Espiritualidad, 1982, págs. 153-189.

2 Ibídem., pág. 154 


\section{2: artículos La Flor del Carmelo. Iconografía y mensaje simbólico...}

1. Vista general de la iglesia del Carmen.

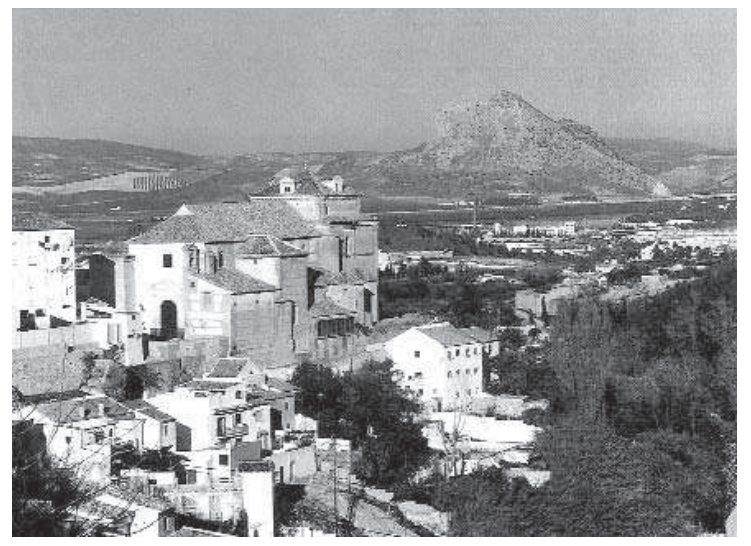

curso del tiempo bajo diversos aspectos. En los siglos XIII y XIV predominaba la imagen de María como Patrona, la Madre de Jesús, Señor de Tierra Santa; en los siglos XIV y XV se prefirió la imagen de la Virgo Purísima, es decir, la Virgen, la Inmaculada, la "mujer del Apocalipsis", la Amiga del Padre Celestial; y desde el siglo XVI hasta nuestros días adquiere preponderancia la Virgen del escapulario, que preserva del infierno y libra del purgatorio. Si bien, la primera advocación estaría presente en la segunda y ambas en la tercera. Es más, desde comienzos del siglo XVII se asocia inmediatamente a la Patrona con el escapulario.

Y precisamente es esta imagen de María como Patrona, Madre de Jesús, y Virgen del escapulario la que preside nuestra iglesia. Ciertamente no conocemos ni el autor ni la fecha en que se realizó dicha talla, pero Jesús Romero cree que se realizó con anterioridad al retablo en el que está situada. La policromía se conoce que se le renovó en el siglo XVIII ${ }^{3}$. Si sabemos que el motivo del escapulario se empezó a difundir en el siglo XVI y alcanzó su apogeo en el XVII, y por lo tanto, la podríamos aproximar a este período de tiempo, pero también es cierto que el escapulario podría ser un añadido posterior a la escultura.

Parece conveniente aclarar dicha figura de María como Patrona y como Virgen del escapulario antes de continuar, aún con el perjuicio de extendernos un poco. Siguiendo al padre Saggi ${ }^{4}$ conocemos que los ermitaños latinos del Monte Carmelo pidieron a Alberto, patriarca de Jerusalén, una regla. Éste les dará en un año impreciso entre 1206 y 1214 una "forma de vida" en la cual no se cita para nada a María. Ello puede hacer pensar que en un principio el elemento mariano no existía en la Orden, pero en esta "forma de vida", que sólo más tarde se denominará "regla", se prescribe que se construya una iglesia en medio de las celdas que han de

3 ROMERO BENITEZ, Jesús.: Guía artística de Antequera, Antequera, Ed. Biblioteca antequerana y Caja de Ahorros de Antequera, 1981, pág. 96.

4 Ibídem. 
2: artículos María José Carmona Mato

habitar. Esta se construyó y se dedicó a la Virgen María. La elección del título de la iglesia en la época feudal llevaba consigo una determinada orientación espiritual, pues, en la concepción feudal el estar al servicio de una iglesia significaba estar al servicio del santo al que se dedicaba la misma. Es más, "servicio" para la mentalidad medieval significaba "consagración personal". Y como en los comienzos de la Orden hallamos una elección mariana, María será considerada por los carmelitas su patrona. El prior general Bernardo Oller en 1376 explica lo que significa para los carmelitas este término: "En sentido activo un patrón es el que inicia o funda una Orden. En sentido pasivo puede ser: a) aquel en cuyo honor se ha fundado una Orden, b) si ha sido libremente escogido y c) si le han dedicado iglesias o casas" 5 . Los carmelitas por el hecho de que sus antepasados le dedicaron a María su primera iglesia decían que la misma había sido fundada en honor de María. De hecho, para el pensamiento feudal la relación entre "patrono" y "cliente" además de basarse en el hecho jurídico se basaba principalmente en lo "vivido". Y es indudable que la Orden "vivió" la devoción a María desde muy pronto. Ahora bien, si así queda claro el título de "Patrona", no es menos cierto -como afirma el padre Hoppenbrouwers ${ }^{6}$ - que el culto a María debió brotar de la doctrina de la fe. La inclinación mariana se centra -como más adelante explicaremos- en su divina maternidad y en su virginidad.

El añadido del escapulario se debe a la visión de S. Simón Stock. Este santo al que los documentos sitúan en el siglo XIII, pero sin acertar a darnos una fecha exacta, pidió a la Virgen un privilegio para su Orden. Según el Catálogo de los Santos Carmelitas la Virgen le entrega el escapulario como prenda de salvación7. El escapulario es un "don" de la Patrona, que incluso llegará a celebrarse como fiesta: la fiesta de la Conmemoración Solemne del mes de julio. Pero, más tarde, se va unir esta visión a la del "privilegio sabatino" de Juan XXII contenida en la "bula sabatina" del año 1322. La Virgen promete al Papa ayuda contra los adversarios si éste ayuda a los carmelitas. Promete también que quién profese en la Orden se salvará eternamente, ella misma bajará al purgatorio el primer sábado después de su muerte para liberar de sus penas a quién lleve el hábito, que es en este caso, la capa blanca. El verdadero significado de esta bula parece ser el asegurar a los "mantelados", es decir, a los que llevan el mantellum o capa, símbolo del hábito, el gozar de los privilegios de la Orden. Con el tiempo ambas visiones se fundieron y el significado del escapulario encerrará también el del "privilegio sabatino". El escapulario, como hemos dicho, preserva del infierno y libra del purgatorio. La fiesta del hábito, que desde entonces se simboliza en el escapulario, se celebra el 16 de junio y asumió las dos visiones ${ }^{8}$.

Pero esta representación mariana es tan sólo la última de un largo recorrido en la vida de la Virgen que comienza en la nave central, en los lienzos que se sitúan

\footnotetext{
5 Ibídem., págs 157-158.

6 Ibídem. págs. $159-160$

7 SAGGI, L.: "Simon Stock" en SAGGI, L. (coor.): Santos... op. cit., págs. 451 y ss.

8 SAGGI, L.: "Santa María...", págs. 185 y 186.
} 


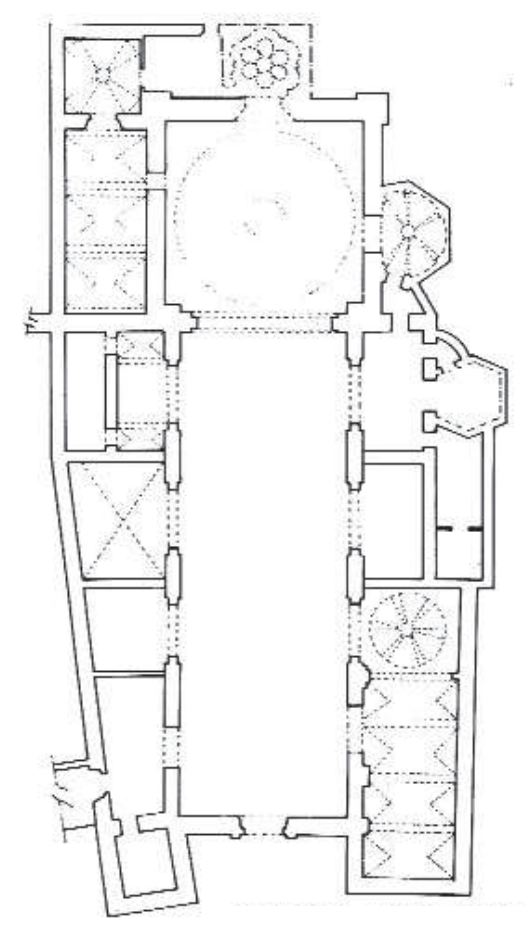

2. Iglesia del Carmen, planta.

en la parte superior de las paredes de misma. Se trata de siete composiciones de amplias dimensiones con escenas relativas a la Virgen María.

\section{LA NAVE CENTRAL: LA SERIE MARIANA.}

Cada uno de los ocho lienzos que forman esta serie se encuentran dentro de un marco de estuco que se corona con frontón partido acabado en volutas, el cual acoge a un jarrón y dos pirámides terminas en bolas, también de estuco, en el centro y los extremos del mismo respectivamente. Estos marcos se sitúan a lo largo de la parte superior de las paredes de la nave central, cuatro en el lado de la Epístola y cuatro en el lado del Evangelio, formando dos parejas en cada lado separadas por un hueco que alberga la ventana. Falta el lienzo que ocuparía el quinto lugar, y por tanto, la serie que estudiamos sólo cuenta con siete cuadros. No conocemos ni el autor ni la fecha exacta en que se realizaron, pero creemos que se puede aproximar a la segunda mitad del siglo XVIII. 


\section{Q: artículos María José Carmona Mato}

Los lienzos del lado de la Epístola representan, siguiendo el sentido contrario al de las agujas del reloj, es decir, de los pies a la cabecera de la Iglesia son: tras uno cuyo tema nos es desconocido, la "Natividad", la "Purificación" y la "Presentación en el templo" de Nuestra Señora. El tema del primero de ellos, como hemos indicado, es difícil de identificar: una figura femenina vestida de carmelita con el hábito carmelitano: la túnica marrón y la capa blanca, que parece flotar en el aire -quizás la Virgen del Carmen-, entra en una estancia en la que están sentados a una mesa dos personajes, uno femenino y otro masculino. Por ser el primero de dicha serie, tal vez pudiera tratarse de la entrada de la Virgen del Carmen en las vidas de San Joaquín y de Santa Ana, pero esto es sólo una sugerencia, pues, la representación es bastante escueta en referencias. En el "Nacimiento" vemos que la escena se representa en una estancia en la que aparece, de frente al espectador, una figura femenina de cierta edad y vestida de blanco echada sobre una cama, parece ser Santa Ana; a su derecha de lado y mirándola, un personaje de más edad con barba blanca que identificamos como San Joaquín. A los pies de la cama dos muchachas jóvenes de perfil, la de la derecha sentada y la de la izquierda de pie, se disponen a secar a la Virgen recién nacida después de haberla lavado, bajo la atenta mirada de su madre que se incorpora para observar la escena. A la izquierda dos personajes cubiertos con capas, que sólo dejan ver parte de su rostro, contemplan todo lo que está ocurriendo. La escena de la "Purificación" nos muestra el momento en que los padres de la Virgen, fieles a las tradiciones hebreas entregan a su hija recién nacida al Sumo Sacerdote para que sea purificada. Éste, que se sitúa detrás del altar, es representado siguiendo la tradición con largas barbas y gorro de dos puntas. El toque religioso de este instante lo ponen los dos jóvenes que están a ambos lados del Sumo Sacerdote y que sostienen cada uno en sus manos un largo y fino cirio encendido, que bien pueden hacer alusión al Antiguo y al Nuevo Testamento, pues, ella actuará de mediadora entre los dos testamentos; y el que situado ante los padres de la Virgen se arrodilla al hacer la humilde ofrenda de dos pichones blancos portados sobre un cuenco de barro. En la "Presentación en el Templo" la composición siguiendo la perspectiva renacentista nos muestra en primer término a la Virgen niña y a Santa Ana. La primera, a la izquierda del espectador, es introducida de la mano en el templo, que aparece al fondo, por la segunda, a la derecha. Ambas figuras aparecen de perfil contrastando con la imagen de San Joaquín, que si bien da la cara al espectador, se sitúa en un segundo plano a la izquierda de María. Santa Ana conduce a su hija hacia el interior del templo donde se encuentran unos personajes que deben de ser las autoridades religiosas, mientras otras personas a su derecha contemplan la escena. Los ropajes de todos los personajes que aparecen en dichos lienzos pretenden ambientar la escena en la época en que se produjeron los acontecimientos. Destacan estos cuadros por sus complejas y bien resueltas composiciones, por sus grandes proporciones y por su colorido en el que predominan los tonos fríos.

Los lienzos del lado del Evangelio también destacan por su gran tamaño pero, se diferencian notablemente de los anteriores por contener cada uno de ellos una 
única imagen, la de la Virgen del Carmen, y por su colorido bastante apagado predominando los tonos marrones. En los tres aparece María con el hábito carmelitano. En primer lugar, siguiendo el sentido de las agujas del reloj, encontramos a " La Virgen del Carmen orante o contemplativa", como "Inmaculada Concepción” y su "Ascensión" a los cielos. En los tres, María aparece vestida con el hábito carmelitano: la túnica marrón y la capa blanca. En el primero de ellos, que realmente es el segundo ya que falta el primero de este lado, encontramos centrando la escena a la Virgen mirando hacia arriba en actitud contemplativa sentada junto a una mesa en la que hay un libro abierto. La mirada de María se dirige hacia las cabezas de angelitos que aparecen en la parte superior de la representación, formando un mismo cielo dentro de la estancia. Los carmelitas debían de imitar a María en su unión con Dios por medio de la oración. Siguiendo el precepto de su regla "Permanezcan meditando día y noche en la ley del Señor" actuaban como la Virgen que "meditaba en su corazón todo lo que veía y oía relacionado con Jesús". En oración se encontraba María en el momento de la Anunciación tan importante para ellos como veremos. El carmelita debe ser un contemplativo, debe meditar profundamente en su corazón la Palabra de Dios. Cuanto mayor sea su comunicación con Dios, mejor logrará escuchar su mensaje, cuyo testigo y apóstol será en la Iglesia. El ideal del Carmelo es el equilibrio entre la vida activa y la contemplativa, de las cuales María es modelo. En la siguiente representación tenemos a la Virgen del Carmen como la "Inmaculada Concepción", en este caso su capa no es blanca sino roja por dentro y azul por fuera, que une sus manos en actitud orante y está coronada por pequeñas cabecitas de angelitos que se unen formando una circunferencia. Se la representa como suspendida en el cielo por un trío de querubines, de cabecita rosadas y alas blancas, que se colocan bajo sus pies a la vez que otro par sostiene su capa. El carmelita historiador de la Orden J. Poleinodoro dice que la fiesta de la Inmaculada fue instituida en el año 1306, y efectivamente la encontramos ya en 1312 en el Ordinale de Siberto de Beka. Además, nos consta que en la controversia sobre la Inmaculada Concepción la Orden siempre defendió el privilegio mariano. Incluso con las celebraciones de dichas fiestas en las iglesias carmelitas, en las cuales según Baconthorp participaba la Curia Romana, se contribuyó al asentamiento de esta doctrina. Este uso siguió en vigor hasta ya avanzado el siglo XV, ya que, las actas de los capítulos generales nos muestran como se imponían tasas a la Orden para la celebración de dicha fiesta9 ${ }^{9}$. En tercer lugar, en la "Asunción" de la Virgen a los cielos, vemos a María con las manos cruzadas delante del pecho y su mirada dirigida hacia arriba que asciende a los cielos sostenida por tres querubines que se colocan a sus pies. La escena parece representar el momento en que la Virgen ha llegado a los cielos, pues, está rodeada de angelitos que revolotean sobre el fondo azul que cubre la totalidad del lienzo.

Pero lo más sobresaliente es que tras este recorrido nos sorprenden dos enormes figuras, que casi podrían ser calificadas de monumentales, pintadas al fresco en

9 SAGGI, L.: op. cit., pág. 175. 
2: artículos María José Carmona Mato

las enjutas del arco toral, una a cada lado. Son la Virgen y el arcángel San Gabriel, es decir, es la escena de una "Anunciación", tema clave para los carmelitas. Romero Beníte $z^{10}$ afirma que se atribuye a Mohedano y apunta el parecido de la composición con la portada del convento de la Encarnación. Lo significativo que este tema es para la Orden queda atestiguado, por las numerosas iglesias carmelitanas que cuentan con representaciones de este momento y la gran cantidad de ellas dedicadas a dicho tema.

Antes de adentrarnos en el tema de la Anunciación es importante que hagamos una pequeña síntesis. Advertimos toda una historia en imágenes. María tiene una infancia como cualquier niña hebrea de su tiempo y cumple con las prescripciones religiosas propias de su cultura, por ello, tras su "nacimiento" es "purificada" y "presentada en el templo". Pero María será escogida para ser la Madre de Dios aún siendo virgen y es reconocida por el arcángel en el momento de la "anunciación" como la Kecharitomene, la llena de gracia,estado que conservará en su madurez con el cultivo de la "oración". Por ello, se la llegará a reconocer como "inmaculada", es decir, la santificada en el seno de Santa Ana, antes de su nacimiento y como prueba de ello subirá "asunta" al cielo. Por todo ello los carmelitas la veneran como modelo de contemplación y de santidad. Esta santidad de la Tota pulchra que se nos revela en la Anunciación (imagen que encontramos en primer plano al entrar en el templo) es la que le permite ser Madre de Dios y "preservar del infierno y librar del purgatorio" como nos indica la Virgen colocada en el camarín, cuya iconografía nos recuerda la acción descendente de María hacia el carmelita Simón Stock, y por tanto, su protección para con la Orden.

Queda claro que de todo el conjunto se quieren resaltar dos temas, frente a los cuales el fiel se encuentra al entrar en la iglesia: la Anunciación y la Maternidad divina de María. La Anunciación es el primer instante de la Encarnación y, como afirma el padre Saggi ${ }^{11}$, si reflexionamos sobre ello, el misterio de la maternidad divina puede tener mucho que ver con el compromiso espiritual de los carmelitas. Como aparece en el prólogo de la regla el ideal de los ermitaños que moraban cerca de la "fuente de Elías" en el Carmelo era "vivir en obsequio de Cristo". En el contexto de aquel tiempo, el de las cruzadas, "obsequio" significaba "servicio" y por tanto se trataba de ayudar a Cristo a recuperar Tierra Santa, patrimonio suyo conquistado con su Sangre. Para los carmelitas Cristo era el Dominum y el "Señor" en sentido feudal. María el ser más cercano a él, y por ello, servirla a ella era como servirlo a él. Además, viviendo en "obsequio" de ella imitaban el obsequium de ella para con Dios. El obsequium feudal incluía los deberes del consilium y del auxilium; esto es, tratar con el que se ha prestado dicho obsequium los intereses comunes y prestar ayuda según las posibilidades de cada cual. María en la Anunciación trató con el arcángel "cómo" cumplir la voluntad de Dios y se ofreció a colaborar en el plan divino. Conocida es su respuesta Ecce anciIla Domini, fiat mihi secumdum verbum tuum. Esto coincidía plenamente con el propo-

\footnotetext{
10 ROMERO BENITEZ, J.: op. cit., pág 98

11 SAGGI, L.: op. cit., pág. 160.
} 


\section{Q: artículos La Flor del Carmelo. Iconografía y mensaje simbólico...}

3. Retablo de San Elías.

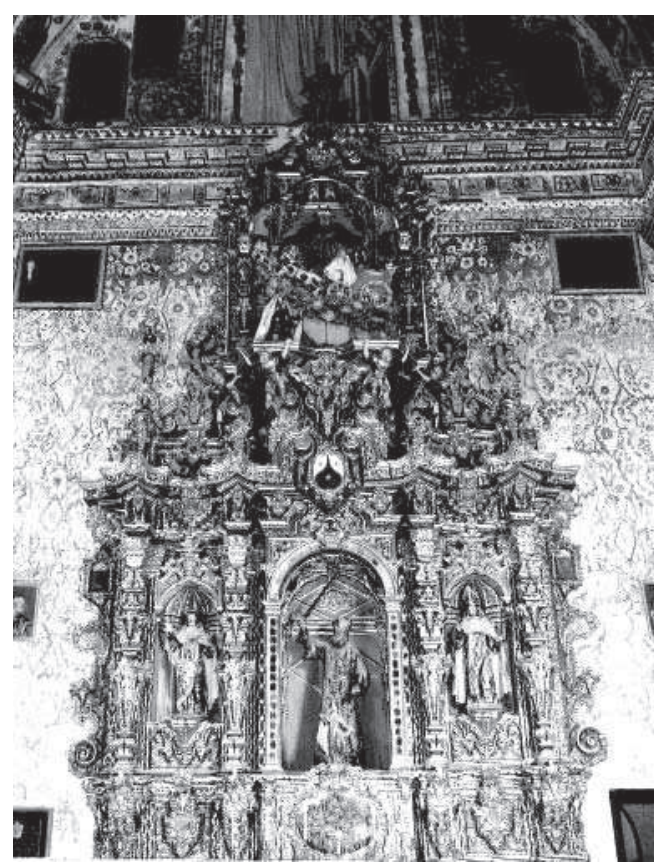

situm de los carmelitas. Es más, la regla insistía en "meditar día y noche en la ley del Señor", para el pensamiento medieval este Señor debería de ser Cristo, y esto era precisamente lo que estaba haciendo María en el momento de la Anunciación, orando. Ludovico Saggi corrobora su tesis citando al padre V. Hoppenbrowers que señala que si la devoción mariana de muchos carmelitas medievales se encauzó hacia el misterio de la Anunciación sería, sin duda, porque de él admiraban la unión con Dios. Más tarde incluso místicos, como Miguel de San Agustín y su discípula María Petijt, resaltarían la mediación mariana en la unión con Dios ${ }^{12}$.

Esto se acentúa también en el hecho de que las fiestas principales de esta Orden, además de la de la Conmemoración Solemne del mes de junio, son las de la Anunciación y la Inmaculada. Destacar, que en ambas se resalta la "virginidad" de María. En la producción literaria carmelitana del siglo XIV se intentan buscar todos los vínculos posibles entre los carmelitas y María. Esta reflexión resaltará principalmente la consonancia entre la virginidad de Elías, Eliseo y sus seguidores y la de María. El historiador de la Orden Chimineto será el primero en ponerlo de relieve. Comenzaba su Speculum, publicado en 1337, con las siguientes palabras: "Hijos de los santos sois mis hermanos..., marcados con el sello de la castidad y honrados con el título de la Virgen María". Otro historiador carmelitano, Felipe Ribot, en su De ins-

12 Ibídem., pág. 165. 
titutione primorum monachorum publicado en 1370 hace remontar este paralelismo a los carmelitas del tiempo de los apóstoles. Señala que estos carmelitas viendo que se habían cumplido las previsiones de Elías acerca de María, la eligieron por Patrona, porque habían conocido que solamente María era conforme a ellos en las primicias de la virginidad voluntaria. Lo que ella inició entre las mujeres, Elías lo había iniciado entre los hombres.

Esta conformidad entre Elías, sus seguidores y María llevó a los primeros carmelitas (ya en tiempo de los apóstoles) a llamarla "Hermana suya" y a sí mismos "Hermanos de la Bienaventurada Virgen María" Pero aún más curiosa es la interpretación que le da esta obra al término "Carmelo" como "ciencia de la circuncisión", que es la adquirida por aquellos que se abstienen de todo pecado contra la castidad de mente y cuerpo, que han de guardar para Dios. En lo cual María es modelo y maestra. Es importante señalar como observa Hoppenbrouwers que la virginidad no era considerada por los carmelitas en su sentido de integridad corporal, sino como virtud que nos une a Dios, es decir, actitud mental con la que todos pueden imitar a la Virgen ${ }^{13}$. De cualquier manera, más que justificarlo históricamente, lo que nos interesa es señalar que en esta época la virginidad de María adquiere importancia para los autores, tanta, que a finales del siglo XV el vocablo "Virgen" se introducirá en el título oficial de la Orden.

Por todo esto es muy significativo que a ambos lados de la imagen de la Anunciación del arco toral se hayan colocado, uno frente al otro, los retratos de Elías y Eliseo. Dichos lienzos se sitúan en unos marcos similares a los de la serie mariana. En ellos, en los que predominan los tonos marrones, dichos profetas están representados en un paraje al aire libre, visten el hábito carmelitano y tienen la misma actitud que muestran en las esculturas del retablo central. Elías aparece como un personaje de cierta edad con el pelo y la barba canos, coronado con el aro de santidad. Mantiene el brazo derecho en alto y sostiene en la mano una espada, símbolo del poder espiritual. San Eliseo se representa de edad madura, calvo y con barba, siguiendo el relato bíblico de II $\operatorname{Re} 2,18-24$ en el que se dice que un grupo de pilluelos se rieron de su calvicie; y dirige su mirada hacia una jarra que vuelca con su mano derecha, haciendo alusión a II $\operatorname{Re} 3,11$ "Eliseo el que vertía agua en las manos de Elías", mientras con la izquierda sujeta una hoz. En un principio, estos lienzos parecían alterar la serie mariana que hemos descrito, pero no es así. Lo que se quiere expresar es precisamente la relación entre la virginidad de María -que queda patente en el momento de la Anunciación- y la de los santos profetas Elías y Eliseo. Es más, esta identidad se acentúa en que dichos profetas al igual que María fueron escogidos por Dios para una misión a la cual ellos -como María- respondieron dedicándole por entero su vida, consagrándose a Dios.

Esta composición de imágenes resultante, tiene su precedente, aunque con variantes, en una figura de María que aparece en el Vexillum Carmelitarum publicado en 1499. Aquí se trata la iconografía de la Inmaculada como la "Mujer del

13 Ibídem., págs. 172, 173 y 174. 
Apocalipsis", la predilecta de Dios, una humanidad nueva, una criatura nueva salida de las manos del creador como Eva. La Virgen no toca la tierra corrompida, no es la "santificada" sino la "preservada". María joven y bella, coronada de estrellas, circundada de la luz del sol y con la media luna bajo sus pies, aplasta la cabeza de la serpiente indicando los méritos del Salvador al que lleva en brazos mientras dos ángeles la transportan al cielo. Los carmelitas de los siglos XIV y XV eligieron esta iconografía para representar a su Virgen, pero además, pronto añadieron junto a ella las figuras de Elías y Eliseo y escriben en un rótulo que sale de su mano "Soy madre y decoro del Carmelo". Esta escena resultante es la del Vexillum Carmelitarum que hemos indicado, pero representaciones muy similares encontramos en el siglo XV en Londres, Bérgamo y Sicilia. Es más, se continuarán durante el siglo XVI y llegarán hasta nuestros días, aunque con modificaciones tan notables como vemos en nuestro caso. En la escena original se resaltaba la pureza integral y la maternidad divina, en nuestra iglesia al hacer referencia a la Anunciación también se hace alusión a los mismos temas aunque más indirectamente. Lo importante es que se unen las imágenes de los "jefes carmelitas" a la de María; ellos son los que conducen al ideal María que es la madre, la fuente de vida, y el ornamento del Carmelo14.

Como vemos, todo este repertorio iconográfico hace referencia a la "Pureza" de María. La capa blanca había ya simbolizado la pureza mariana en el De Institutione... de Ribot, en el Viridarium de J. Grossi, e incluso Baconthorp la llamará pallium de María y Armacano ya en el siglo XIV relacionó su blancura con la Inmaculada. Pero será sobre todo Santa Magdalena de Pazzi quien ejercerá mayor influjo sobre los carmelitas con la constante alusión en sus escritos a esta característica de la Virgen. Para ella "Pureza" lejos de significar solamente ausencia de pecado, significaba "la fuente de todo ser". La verdadera pureza se encuentra en la unión de María con el Verbo en la divina maternidad, así el ser humano solamente en la conformación con Dios y en la participación en su ser divino puede llegar a gozar de esta pureza. Llega a afirmar que verdaderamente no sabe que es la pureza ${ }^{15}$. Por tanto, el culto a la Purísima será una característica esencial de los carmelitas. Dicho culto a la Purísima era continuación del culto a la Anunciación, ya que, como hemos visto, fue la pureza de María la que la unió con Dios.

Concluyendo, desde el siglo XIII los carmelitas han resaltado sus vínculos con María. A partir del siglo XIV ya comienzan a elaborar los argumentos de la relación que la Virginidad, la Inmaculada Concepción y la Maternidad divina tenían con la Orden. Por ello, pronto estos misterios serán celebrados en la misma. Incluso los sintetizan en la definición que dan de su titular como la "Patrona, la Madre Purísima de Cristo, Hijo de Dios". La clave está en la "Pureza" -refiriéndonos con este término tanto a la virginidad como a la ausencia de pecado- la cual es esencial para la

14 Ibídem., nota 41.

15 Ibídem., págs. 178 y 179. 
perfecta unión con Dios. María obtuvo la más perfecta unión con Dios, tanto física como moralmente, en la Anunciación, instante previo de la Encarnación. Por ello la Orden esta "dedicada", es decir, "consagrada" a ella desde su fundación. Como María se encontraba en oración en el momento de la Anunciación, los carmelitas han de practicar la contemplación para llegar a una verdadera unión con Dios. Es más, deben de imitar en todo e intentar alcanzar la pureza de su titular. Por ello, María será la personificación del ideal carmelitano.

Una vez expuesta la primera línea temática, pasemos a la segunda, la que habíamos definido como "eliana". Constatamos que queda bien claro que la Orden del Carmen se caracteriza por basarse en el hecho del lugar privilegiado que en la misma ocupa María. Pasando a la segunda línea vemos que la "tradición" del Carmelo, tiene como su fundador a Elías y tras él elabora una sucesión ininterrumpida de santos que empezando por Eliseo llega hasta nuestros días. Esto nos muestra el prestigio que desde un principio quisieron dar los carmelitas a su Orden. Es más, insistieron en dar a sus religiosos una fisonomía propia que los distinguiese de las demás órdenes religiosas. Y así, encontramos que los dos elementos identificativos de los carmelitas serán precisamente el ser "marianos" y el ser "elianos". Esto les ayudará a resaltar el concepto de Orden con regla propia y título propio aprobados por la Santa Sede, que desde el siglo XIII se preocupan por destacar. Por otra parte, es cierto que la regla dada por San Alberto no hace referencia ni a María, ni a San Elías, fue J. Baconthorp en la primera mitad del siglo XIV quién por primera vez unió ambas devociones. Así lo muestra en su Speculum de Institutione Ordinis cap. I, "Ios frailes del Carmelo, que en tiempos de Elías y Eliseo veneraban también al que había de venir, fundaron además en el Carmelo su Orden de Santa María. Por consiguiente, para este título tuvieron su origen". Esta defensa de sus orígenes ha sido una constante en la historia de la Orden. Destaca sobre todo en los siglos XIV y XV e incluso desembocará en el famoso litigio con Daniel Papenbroeck. En los momentos de crisis o inestabilidad el Carmelo echará mano de aquello de lo cual se siente más orgulloso y con lo que apoya su convicción sobre sus orígenes: sus santos.

Poco importa que estos santos no hayan sido canonizados, sean prácticamente desconocidos e incluso que las biografías de muchos de ellos estén llenas de episodios legendarios. Es conocido como desde la Edad Media la historia sagrada estaba cargada de leyendas en las que se narraban la amistad de ciertos santos con los ángeles, como expulsaban demonios, sufrían en extremo o poseían increíbles virtudes. A partir del Concilio de Trento, con la Reforma protestante esta forma de historiar se depura y se hace más crítica, pero el historiador del arte debe de conocer tanto estas fantásticas narraciones, de las que existían recopilaciones que el artista conocía por tradición o por algún mentor eclesiástico, como la forma de representarlas los artistas, pues, muchas veces proceden de ellas los atributos o son la fuente para identificar una escena representada. En nuestro caso estos santos que encarnan el espíritu de la Orden, corroboran con su presencia, la cual nos remite a su vida y virtudes, la antigüedad y grandeza de la Orden. Por ello, es importante, seguir el recorrido en el tiempo de la misma. 
Situándonos en la época y ambiente de cada uno de estos personajes, y deduciendo lo que supuso la presencia de cada uno de ellos en su tiempo para el Carmelo, llegaremos a comprender el verdadero significado de su presencia en esta iglesia.

Es necesario aclarar, que la denominación de "línea eliana" la dimos en cuanto nos ayudaba a sintetizar las dos directrices que definen la iconografía de la iglesia. En realidad, se trata de Elías y de sus sucesores: los santos del Carmelo. Así, esta segunda directriz comenzaría en el retablo central para extenderse a los laterales y tras invadir el púlpito pasaría a la nave central. Dada la gran extensión de la misma la podríamos dividir en dos partes: la eliana y la de los santos del Carmelo.

\section{Línea Eliana: el retablo central.}

La línea eliana propiamente dicha también comienza en el retablo central. La belleza de este retablo se debe a la magnífica articulación conseguida entre su base arquitectónica y su abigarrada decoración. Su ofuscamiento dota al conjunto de una gracia sin igual. La estructura arquitectónica, que cubre un espacio cóncavo se divide en altura en tres cuerpos sobre el banco que se coronan con un gran peinetón. En anchura tanto el banco como los dos primeros cuerpos se divide en tres ejes o calles. El tercer cuerpo tiene forma semicircular y lo ocupa un cascarón entre las pechinas de la bóveda. Enmarcan el conjunto dos anchos pilares laterales que se continúan en la parte superior en un arco carpanel, el cual circunda los lunetos del cascarón. Pero esta cerrada estructura la va a romper el peinetón que, elevándose hacia la linterna de la cúpula, se colocará en la cima de la misma. En cuanto a la decoración, tanto arquitectónica como escultórica del retablo, encontramos en el primer cuerpo en el centro de la calle del lado del Evangelio un rosetón con la figura tallada de medio cuerpo del Salvador con una bola del mundo en su mano izquierda, y con la derecha levantada e actitud de bendecir. En el centro del eje del lado de la Epístola otro con la figura de la Virgen también de medio cuerpo. En la calle central, bastante más ancha que las laterales, quizás el doble, se sitúa el camarín de la Virgen del Carmen que ocupa también parte de la calle central del segundo cuerpo, y sobre el mismo un rosetón con la figura tallada de medio cuerpo de San Elías calvo y con barbas. Rodea el círculo la inscripción: Ordo Prophetarum y bajo él cuelga del retablo una banda en la que está escrita: "Ipse es Elías". Las calles o ejes de este segundo cuerpo están separadas por recargados estípites. Cada uno de estos ejes cuenta con una decoración arquitectónica de quebradas cornisas que cubren cortinajes simulados y hornacinas que albergarán a una significativa imaginería. Las esculturas se extienden también a los pilares laterales, es más, en el centro de los mismos encontramos sendos óvalos con relieves de medio cuerpo esculpidos en madera de Santa Ángela de Bohemia, a la izquierda, y Santa Magdalena de Pazzi a la derecha. En el rizado peinetón, que con sus movidas formas aún le aporta más alegría al conjunto, también se colocará una dinámica talla. Actualmente se atribuye su traza y ejecución al maestro entallador antequerano Antonio Primo. Su parecido 


\section{Q: artículos Maria José Carmona Mato}

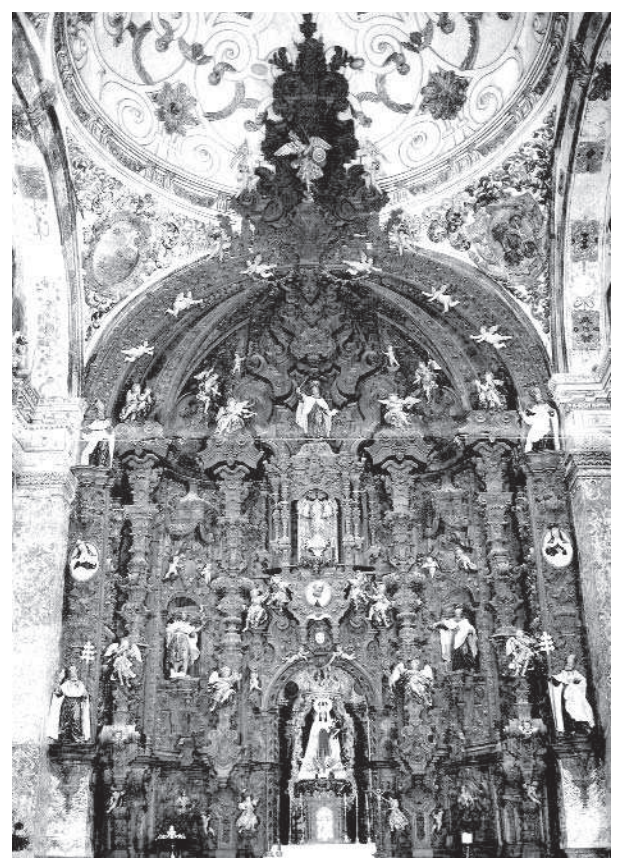

4. Retablo mayor de la iglesia del Carmen, vista general.

con los retablos mayores de Las Carmelitas Descalzas de Lucena (1738) y con el de los Remedios de Estepa (1760), del mismo autor, parece confirmarlo. Al parecer se realizó en los años anteriores a 1747. Esta gran pieza es -según Jesús Romero- uno de los más interesantes ejemplos de retablística barroca andaluza del siglo XVIII 16 .

Antes de adentrarnos en el repertorio eliano es necesario destacar la presencia de una pequeña talla en este retablo. En el amplio segundo cuerpo, sobre el camarín de la Virgen del Carmen encontramos, formando parte de la misma estructura del retablo, encerrada en una especie de hornacina rodeada de pequeños estípites y profusa decoración (casi podría definirse como una diminuta capillita) la figura de una pequeña Virgen. Sobre ella se sitúa la imagen de San Elías. Quizás el repetir el tema mariano en el retablo se deba a la insistencia -como ya hemos apuntado- de hacer ver que el camarín es dentro del retablo un espacio auténticamente autónomo. Es decir, en recalcar que dicho retablo no es más que el marco del mismo. Esto nos parece querer indicar que aunque Elías se sitúe a un nivel central e incluso superior a María, no hay que olvidar que la Virgen es la que ocupa el primer plano, el lugar principal en la Orden.

16 ROMERO BENITEZ, J.: op. cit., pág. 94. 
Pero es en el despliegue de santos de la Orden que se dan cita en este segundo cuerpo del retablo dónde se va a empezar a desarrollar una verdadera apología del Carmelo, que luego se continuará por todo el templo. Todos estos personajes están vestidos con el hábito carmelitano, aunque cada uno aparece con los distintivos característicos de su jerarquía eclesiástica. En primer lugar tenemos a Elías, sobre la pequeña virgencita, con el pelo y la barba canos y con el halo o nimbo de santidad. Mantiene el brazo derecho en alto y sostiene con la mano una espada, símbolo del poder espiritual, el brazo izquierdo lo tiene bajado y en esta mano mantiene un libro abierto, lo cual lo identifica como defensor de las escrituras. Sobre él, dentro del peinetón que corona el retablo advertimos -difícilmente dada la gran altura a que se encuentra- la figura de San Miguel arcángel que aparece como guerrero con escudo y flecha, que pisa con el pié la cabeza del fácil de identificar por ser un reptil de lengua bífida. La escena destaca por su fuerza y movimiento. Junto a la misma, en los lunetos del cascarón, una a cada lado, las tallas de los arcángeles San Gabriel y San Rafael que mantienen los brazos en alto sosteniendo atributos guerreros. Ambos se apoyan sobre una rodilla en una peineta pequeña y les falta una pierna. Seguramente el escultor a sabiendas de que esta pierna no se vería desde ningún punto de vista optó por no hacerla. A cada lado de San Elías en las calles adyacentes y a un nivel inferior encontramos a San Eliseo y a San Juan Bautista, a derecha e izquierda del espectador respectivamente. Eliseo calvo haciendo referencia a II $\operatorname{Re} 2,18-24$, con grandes barbas y con halo de santidad sostiene con la mano derecha una jarra, haciendo alusión a II Re, 3, 11 "Eliseo el que vertía agua en las manos de Elías"17. San Juan Bautista, también con nimbo de santidad, fiel a la iconografía que lo identifica va vestido con pieles de camello, porta el bastón-cruz en la mano izquierda y a sus pies tiene un cordero. Estas tres figuras forman el grupo escultórico central. Es necesario aclarar que en todas las descripciones de los retablos que se hacen en este trabajo siempre vamos a indicar la posición de las imágenes con respecto al lugar que ocupen según la mirada de frente del espectador, como hemos hecho en este caso.

Más al exterior, en los pilares que enmarcan el retablo, reconocemos a ambos lados las figuras de dos obispos, arzobispos o patriarcas en la superior, y de dos papas en la inferior, como muestran las mitras y tiaras respectivas. Por llevar estos dos personajes superiores el "palio" de patriarca en oriente, correspondiente al de arzobispo en occidente (el "palio" es la capita que se coloca sobre la capa blanca carmelitana) los podemos identificar como tales. Podrían, por tanto, tratarse de San Cirilo de Alejandría a la izquierda y de San Alberto de Jerusalén a la derecha. La representación de ambos personajes es casi idéntica: de cierta edad y con barba, mantienen las dos manos levantadas a la altura del pecho y miran hacia su mano izquierda. La postura del de la izquierda parece indicarnos que podría haber llevado en su mano izquierda el atributo de la cruz patriarcal; la derecha la tiene extendida.

17 SPADAFORA, F.: "Eliseo, profeta, santo", en SAGGI, L. (Coord): op. cit., págs. 293-296. 
2: artículos María José Carmona Mato

El ademán del de la derecha parece mirar a un posible libro que podría haber sostenido con su mano izquierda, mientras llevaría en la derecha la cruz patriarcal. Pero hay que recordar que esto es sólo una aproximación, ya que, al faltarles los atributos es difícil de conocer con certeza si verdaderamente son tales personajes. Por su rango eclesiástico cabría también la posibilidad de que fuesen San Pedro Tomás y San Andrés Corsino, ambos muy venerados en la Orden. En cuanto a los papas los dos dirigen su mirada hacia la cruz papal de tres brazos la cual portan, el de la izquierda con la izquierda, y el otro con la derecha. El primero sostiene con la otra mano un cáliz con tres sagradas formas sobre él formando un triángulo. Este atributo lo identifica como San Telesforo y hace alusión al hecho de que este papa instituyó el celebrar tres Misas de Navidad: la de media noche, cuando nació el Niño Jesús; al romper el alba, cuando fue adorado por los pastores, y la de la hora de Tercia, es decir, la llamada de la Conmemoración Solemne del día de Navidad, en señal de la luz que vino a traer al mundo. También significan respectivamente la generación eterna del Verbo en el entendimiento del Padre; su nacimiento temporal en Belén; y la conversión de los pecadores. El otro carece de atributos más explícitamente identificativos pero debe de ser San Dionisio, pues, la Orden sólo rinde culto a estos dos papas. En cada pilar entre Papa y obispo encontramos sendos óvalos con relieves esculpidos de medio cuerpo de dos santas: Santa Ángela de Bohemia y Santa Magdalena de Pazzi. La primera, a la izquierda, coronada, indicando su rango de princesa, pues era hija del rey de Bohemia Ladislao II, coge un tarro en su mano izquierda que podría ser de perfume; la segunda, a la derecha, con nimbo, parece haber sostenido en sus manos una cruz. Dicha cruz lo más probable es que aludiendo, dada la preocupación de la santa por la salvación de las almas, a la "Sangre preciosa de Jesús" derramada para redimir a toda la toda humanidad, que ella tanto amaba, como dice en sus escritos. Ambas santas están representadas exactamente igual que en el púlpito dónde están esculpidas con sus nombres correspondientes.

Pero lo que le aporta al retablo su singular alegría es el hecho de que por toda la extensión del mismo se sitúan, como si estuvieran revoloteando alrededor de él, figuras de angelitos pequeños y adolescentes. Éstos con sus diferentes actitudes y actividades: tocan instrumentos musicales, sostienen cartelas o guirnaldas, unen sus manos en actitud orante o tocan palmas, dotan al conjunto de un dinamismo muy particular. Dinamismo al que contribuye el movimiento de las capas de los personajes. Es más, el color blanco de dichas capas, las carnaciones rosáceas de las figuras y los rostros delicados de cabellos rubios de la corte celestial, contribuyen a crear una luminosa policromía que contrasta muy favorablemente con el color de la arquitectura en madera del retablo que permanece sin dorar. Con todo lo dicho el didactismo del retablo central queda patente. Contribuye a ello la buena y jerarquizada distribución de las imágenes en el mismo. La lectura, pues, es la siguiente: el fundador de los carmelitas al igual que la titular de dicha Orden han logrado con su santidad vencer al mal, es decir, aplastar la cabeza al demonio. Esta santidad continuará tras él en sus más inmediatos sucesores. 
Es más, la imitación de estos eremitas llegará a ser tan numerosa que formarán una gran Orden. A dicha Orden pertenecerán santas tan piadosas y santos tan virtuosos e inteligentes que incluso serán personas ilustres fuera de la misma, ocupando puestos principales en la jerarquía eclesiástica. Es más estos personajes al encontrarse rodeados de una corte celestial es como si se encontrasen en el cielo rodeando a la Virgen.

Pero profundicemos un poco más en lo que estos personajes significan para la Orden y lo que aquí nos quieren transmitir. Elías, cuya vida se nos narra en I Re 17 y en II Re 1, como su mismo nombre indica "Yahvé es Dios" será el defensor del monoteísmo de Yahvé. Su figura quedará unida a la de Moisés ya que si uno es el que pacta con Dios la Alianza, el otro es el que la conserva y cuida su pureza. Ambos aparecen en la Transfiguración de Jesús en el Monte Tabor, lo cual nos indica que la Nueva Alianza continúa y supera a la Antigua. San Justino y San Ireneo destacan su gran personalidad y lo ponen como modelo de perfección. Orígenes destaca el poder de su oración. Su gran intimidad con Dios se debe, según los Santos Padres, a su pureza de corazón. Es como María modelo de vida activa y contemplativa ${ }^{18}$. Eliseo "Dios es mi salvación", cuyo ciclo se nos narra en II Re 2-13, heredará su espíritu y será su sucesor. Ambos realizaron un buen número de milagros y habitaron en el Monte Carmelo. Por vivir en este lugar se les ha considerado como los primeros eremitas, cuyas vidas se centraban en la oración y en la actividad profética. También San Juan Bautista, que según la Biblia vivía en el desierto, ha sido considerado desde siempre como sucesor de Elías ${ }^{19}$. Por lo tanto, estos tres profetas nos aparecen como prototipos de la vida religiosa en soledad. El mismo San Ambrosio dirá de ellos que "realizaron esta feliz huida del mundo hacia el desierto"20.

Con todo, la imagen tradicional y más sobresaliente de Elías en la Biblia es la de precursor del Mesías. Esto se debe a que la profecía de Malaquías en 3, 1 y 23-24 siempre se entendió así. Esta creencia seguía vigente aún en tiempos de Jesús pues los Evangelios refieren que el pueblo le pregunta si Él es Elías como en Jn 1, 21; o si Elías vendrá antes del Mesías Mt 17, 10-13 y Mc 9, 11-1321. San Justino (Dial 49,5) interpreta la respuesta de Jesús en estos dos pasajes en el sentido de que a Elías ya lo vimos en la figura de San Juan Bautista22. También en Lc 1,17 se nos dice que la profecía de Malaquías se realizará en San Juan Bautista, Este es el precursor vaticinado que encarnará "el espíritu y la fuerza de Elías" el cual fue tan sólo figura suya ${ }^{23}$. Para San Gregorio de Nisa la relación entre ambos es evi-

18 SPADAFORA, F.: op. cit., págs 196-198.

19 STRAMARE, T.: "Eliseo" en SAGGI, L. (coord): op. cit., págs 289-291.

20 PETERS, C.: "Elías, profeta, santo" en SAGGI, L. (coord): op. cit., págs. 199-207.

21 STRAMARE, T.: "Elías profeta, santo" en SAGGI, L. (Coord.): op. cit., pág. 192.

22 BENOIT, P., BOISMARD, M. E. y MALILLOS, J. L.: Sinopsis de los cuatro evangelios. Bilbao, Ed. Desclée de Brouwer, 1987, pág. 155.

23 STRAMARE, T.: op. cit., pág. 192.

24 SPADAFORA, F.: op. cit., pág. 196 
Q: artículos María José Carmona Mato

dente 24 . También a Eliseo, dada la semejanza entre los hechos acaecidos en su vida y los ocurridos en la vida de Jesús, se le consideró "prefigura" suya 25 . En cuanto al Mesías, es anunciado en Jeremías 23, 5; Ez 34, 23 e Is 11, 1-10; 42, 1-9 como "el Siervo de Yahvé, David"26. De ello podemos deducir la imagen de Jesús como "Siervo de Yahvé" o "Varón de Dolores" que aparece en el retablo del lado de la Epístola. A la izquierda los precursores Elías y Eliseo y a la derecha el Mesías.

Quizás, lo dicho aún sea insuficiente para aclarar el por qué de la relación de los carmelitas con el profeta Elías. Pues bien, dicha relación está en el origen mismo de la Orden. Según el primer documento que existió sobre ello, la regla dada por el patriarca de .Jerusalén, Alberto, a la que ya hemos hecho alusión, los religiosos del Monte Carmelo se encuentran reunidos "cerca de la fuente". Según Jacobo de Vitry se trata de la llamada "fuente de Elías, dónde a imitación de Elías llevan una vida solitaria...". Si bien la regla no habla de una inspiración eliana de la vida carmelitana, sí parece probable que la devoción a este santo se deba al hecho de que habitó en el Monte Carmelo. Los carmelitas se sentirían deudores de su espiritualidad y esto daría pie a la leyenda de una vida eremítica ininterrumpida desde Elías hasta el tiempo en que se instituyó la regla. La Rubrica Prima de las constituciones del Capítulo de Londres del año 1281 confirma esta idea: "Desde los tiempos de Elías y Eliseo que habitaron en el Carmelo siempre ha habido allí imitadores suyos, sus sucesores recibieron la regla de San Alberto, después de que éste los reuniera en un collegium, nosotros somos sus seguidores"27. Adviértanse dos términos que serán muy significativos más adelante la "imitación" y la "sucesión" de Elías. De todo ello se desprende el lugar principal de estas tres imágenes en el retablo.

\section{Los santos del Carmelo.}

En cuanto a los obispos, papas y santas forman un segundo grupo dentro del retablo de los cuales podemos aportar unos cuantos datos biográficos que nos ayudarán a comprender el conjunto. Pasando a los primeros tenemos a San Alberto que nace hacia la mitad del siglo XII en Castrum Gualteri, de la familia de los Avogadro o de los condes de Sabbioneta. En 1184 es nombrado obispo de Bobbio y al año siguiente se le traslada a Vercelli. Inocencio III, que le tenía en gran estima y alababa su sabiduría, prudencia y fortaleza, le encarga importantes misiones nacionales e internacionales, incluso tras ser nombrado patriarca de Jerusalén en el año 1205. Llega a Palestina en 1205 y al no poder instalarse en esta ciudad por estar ocupada por los sarracenos se instala en San Juan de Acre. Pero por lo que se le venera en la Orden del Carmen es por el hecho de que hacia el año 1208-1209 escribió la "norma de vida" o "regla" de los carmelitas, a la cual ya hemos hecho referencia. Esta ha de

25 STRAMARE, T.: op. cit., pág. 293.

26 Ibídem., pág. 192.

27 SAGGI, L.: "Hagiografía carmelitana" en SAGGI, L.(Coord.): op. cit., págs. 40-41. 


\section{Q: artículos La Flor del Carmelo. Iconografía y mensaje simbólico...}

5. Virgen del Carmen, epicentro del programa iconografico.

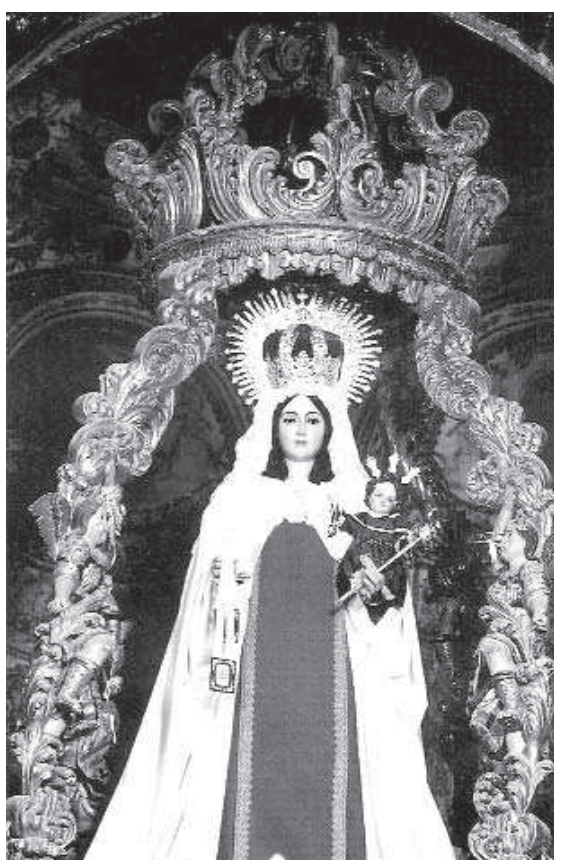

ser considerada como un importante texto de la espiritualidad medieval. El texto que refleja su espíritu en las prescripciones disciplinares, codifica lo que era la tradición monástica del Carmelo. Insiste en el silencio interior y exterior, en el recogimiento y desprendimiento, que predisponen a la oración y en la meditación de la Palabra de Dios. Esta regla sigue siendo la ley básica de la formación y disciplina religiosa de los carmelitas, por ello, esta Orden venera a Alberto como a su legislador. Fue asesinado a puñaladas en 1214 en Acón, en una procesión por una persona a la que había justamente destituido de su cargo. Actualmente la fiesta de San Alberto se celebra el 17 de septiembre en las dos ramas de la Orden con el grado de "fiesta" Los atributos iconográficos de este santo son un crucifijo y un puñal, así lo representó Dosso Dossi en la Iglesia del Carmen de Módena. P. Lorenzetti lo pintó entregando la Regla a B (se cree que debe de referirse San Brocardo) en el Carmen de Siena ${ }^{28}$. En cuanto a San Cirilo de Alejandría sabemos que en esta Orden, curiosamente, se le rinde culto por equivocación. El Carmelo veneró desde antiguo a un tal Cirilo de Constantinopla, pero, más adelante se le llegó a confundir con su homónimo Cirilo de Alejandría. Una vez aclarada la confusión la Orden decidió venerarlo también y fue incluido en la litur-

28 STARING, A. (O. Carm.). y RUOCCO, R.: "Alberto, patriarca de Jerusalén, santo" en SAGGI, L. (coord.): op. cit., págs. 215-218. 
2: artículos María José Carmona Mato

gia carmelitana como de la propia Orden ordinis nostri. La fama de este Cirilo, que nació en Alejandría y fue elevado a la sede patriarcal de dicha ciudad en el año 412, se debe a su actividad como defensor de la fe ortodoxa cristiana frente al patriarca constantinopolitano Nestorio. Éste negaba la unidad de persona en Cristo y la maternidad divina de María. Decía que María sólo era Madre de Jesús, no de Dios. Cirilo combatió la doctrina de Nestorio hasta que el Concilio de Éfeso (431) condenó a este último de herejía y lo depuso de su sede ${ }^{29}$. Por ello, para los carmelitas fue fácil incluir en su santoral al patriarca de Alejandría ya que había sido el defensor de la verdadera imagen de su titular y patrona. Es más, según parece, Cirilo, que en un principio se caracterizó por su carácter impetuoso y casi inconsiderado, terminó siendo un santo. Incluso se afirma que se retiró al desierto dónde practicó una vida ascética. Esto lo acerca y asemeja aún más al espíritu carmelitano.

De los segundos conocemos que el papado de San Telesforo, el cual era de origen griego, duró 11 años, del 125 al 136. San Ireneo nos dice que murió mártir, degollado, en tiempos de Adriano ${ }^{30}$. Antes de su elevación al solio pontificio se había afiliado al instituto de Elías, tomando el hábito y profesando en uno de los monasterios de Palestina. Al parecer los carmelitas lo introdujeron en su santoral por este hecho y además por destacarse en su pontificado por haber combatido algunas herejías entre las que destaca la de Valentín, que ponía en entre dicho algo tan importante para los carmelitanos era el hecho de que Jesús fuera verdaderamente hombre e hijo de María. Valentín enseñaba que Jesús nació de la Virgen pasando por ella velut per canalem, como pasa el agua por un canal, sin tomar su carne, revestido de una carne celeste, no humana como la nuestra31. San Dionisio, como el anterior, también era de nacionalidad griega y pasó del Carmelo Solio Pontificio. Su filiación a la Orden de los Carmelitas la confirma, según el libro del padre Besalduch al que seguimos ${ }^{32}$, el Breviario en la IV lección del día de su fiesta que afirma que profesó por algún tiempo la vida anacorética o monástica; y de allí fue elevado al Sumo Pontificado. Además en el mismo Breviario, así como en el Misal y calendarios publicados con la aprobación de la Iglesia, aparece San Dionisio con el doble título de "Papa y Carmelita". Además destaca este libro que la iconografía lo pinta y esculpe desde los más remotos tiempos con el hábito carmelita. Es más, nos dice que así consta por unas pinturas en tabla antiquísimas que se conservaban en Bruselas, Verona, París, Venecia y Roma según escribe un biógrafo del santo, Pedro Lucio y señala Alegre de Casanate que hace referencia a unas planchas de cobre, muy antiguas, que poseían los Carmelitas Descalzos de Salamanca. En su pontificado que duró del 250 al 268, sobresalió por su caridad, su papel en relación al bautismo de los herejes, y por haber reorganizado la Iglesia romana una vez restituidos a la Iglesia los bienes conquistados por Galiano ${ }^{33}$, pero sobre

29 AZNAR TELLO, S.: "San Cirilo de Alejandría" en Gran Enciclopedia Rialp, Madrid, Ed. Rialp, S.A., 1971, págs. 667-669.

30 CASTELLÓ, G.: Historia de los Papas, t. I, Madrid, Ed. Espasa Calpe, S.A.,1970.

31 Ibídem.

32 Ibídem. 
todo destacó en su lucha contra las herejías de Sabelio y Pablo de Samosata, revelándose como un gran defensor de la Trinidad y de la Maternidad divina de María, debiéndole en buena parte los carmelitas el poder seguir venerando a su patrona como Madre de Dios. Frente al sabelianismo que defendía la unidad de persona y de naturaleza en Dios, y, asimismo, negaba la consubstancialidad del Hijo con el Padre, defendió la doctrina ortodoxa católica que afirma una única naturaleza y tres personas en Dios. Incluso reunió un concilio en Roma en el año 262 donde expuso esta doctrina de la Santísima Trinidad. También condenó la subordinación de Pablo de Samosata que afirmaba que el Hijo está subordinado al Padre y enseñaba que Cristo no era Dios y la Virgen no era verdadera Madre de Dios y era, por tanto, un antecedente del arrianismo, y el milenarismo. Contra esta herejía convocó otro Concilio en Antioquía en el año 266. Se mantiene el interrogante sobre su martirio.

En relación a las santas tenemos que Santa Magdalena de Pazzi, la santa italiana más ilustre de la Orden. Santa Ángela de Bohemia debió de ser uno de estos personajes legendarios en la Orden, pues, su biografía no aparece en las actuales recopilaciones de santos carmelitas que se tratan desde un punto de vista crítico y científico. Solamente conocemos que en una pintura de San Felice del Benaco de 1470 que tiene como figura central a San Alberto rodeado de 14 medallones, aparece la imagen de dicha santa en uno de ellos haciendo pareja con la beata Juana de Tolosa ${ }^{34}$. Debió de ser, sin lugar a dudas, un personaje muy importante pues ocupa un lugar principal en esta iglesia como es el retablo central. Es más, hace pareja con Santa Magdalena de Pazzi, la cual hubiera sido la figura más importante de la Orden si no se hubiese visto relegada a un segundo plano por la arrolladora personalidad de Santa Teresa. En esta iglesia encontramos representada a Santa Magdalena por todas partes: en el retablo central, en el púlpito y en un lienzo de la nave central, incluso se le dedica una de las capillas laterales. De Santa Magdalena destaca su personalidad, una de las más singulares y de más sutil sensibilidad de los santos de la Orden, pero también sobresalen sus escritos y su labor en la reforma religiosa. Por ello, vamos a extendernos un poco más en su biografía. Nace en Florencia en 1566 y a los 12 años tiene su primer éxtasis. A los 16 años entra en el convento de Santa María de los Ángeles de su ciudad, padece una extraña enfermedad y desahuciada hace profesión de fe. Se recupera y desde entonces su vida es una sucesión de visiones, éxtasis y otros fenómenos místicos. En sus visiones siente que recibe la corona de espinas de Jesús, le fueron impresos para siempre los estigmas invisibles en el alma, intercambio de su corazón con el de .Jesús, participa de los dolores de la Pasión, San Agustín le escribe en el alma las palabra, Verbum caro factum est. Su vida fue un tormento dados los sufrimientos tanto físicos como morales que padeció. El prior del convento le pidió que relatara sus visiones al volver en sí pero ella no recordaba casi nada. Así, que pidió a las monjas del convento que escribieran cuanto viesen, y estas narraciones ocupan cinco

33 "San Dionisio" en Gran Enciclopedia Larousse, t. 3, Ed. Planeta; CASTELLÓ, G.: op. cit.

34 SAGGI, L.: "Hagiografía..." op. cit., pág 139, nota 269. 
2: artículos María José Carmona Mato

libros que se conservan en el archivo del monasterio de Santa Maria de los Ángeles de Florencia. En ellos se relata que estando en éxtasis hacía otras labores como cocinar, barrer, etc., aunque se comportaba como si estuviera muy lejos.

En la capilla lateral dedicada a esta santa hay varios cuadritos que representan estos momentos. En uno se la ve como mientras fregaba sufre uno de estos arrebatos, en otro se representan las múltiples visiones que al parecer tuvo, etc. Sus visiones eran de tipo intelectual ya que se dice que "veía a la Virgen con los ojos de la mente". En estos escritos se advierte la influencia en esta santa de las Sagradas Escrituras, los "Soliloquios" de San Agustín, los escritos de Santa Catalina de Siena, las meditaciones sobre la Pasión de Jesús del jesuita Loarte y la teología tomista. Por ello, son portadores de una doctrina espiritual compleja, profunda e interesante. Se centra esta doctrina en el "Amor". Dios es amor y la creación se debe al exceso de amor de Dios. Pero este amor aún se refleja con más intensidad en la segunda creación mediante la "Sangre" de Cristo. La vuelta del hombre a Dios se concibe como una lucha entre el amor propio y el amor divino. Esta unión rota por el orgullo y la soberbia sólo la puede restablecer la humildad. Por medio de las virtudes cardinales el alma camina hacia Dios y se une a Él por las virtudes teologales. El amor marca este proceso. Señala la Eucaristía como sacramento del amor con Dios y el prójimo. La unión del alma con Dios exige la purificación hasta el aniquilamiento. El alma transformada no pasará por el purgatorio y tendrá una muerte de amor. La vida espiritual es para ella un círculo animado por el amor. Sus escritos ejercerán mucha influencia en la espiritualidad de los siglos XVII y XVIII, sobre todo en Italia, y especialmente en San Alfonso María de Ligorio. Hay una aparente renuncia a la acción en la santa de Pazzi, pero esto lejos de asemejarse a las doctrinas quietistas del siglo XVII, significa un abandono total a la voluntad de Dios dejando que sea Él el que actúe. En tercer lugar Santa Magdalena será muy sensible a los problemas de la Contrarreforma. Tras la revuelta protestante en muchas zonas de Italia se pide una reforma religiosa. Promoverá las reformas tanto en lo referente a su expansión como a una reforma interior de la misma. Tras numerosos milagros obtenidos por su intercesión Clemente IX la proclama santa en 1669. La liturgia lo honra el 25 de mayo como "memoria libre" para la iglesia universal, "memoria obligatoria" para los carmelitas descalzos y "fiesta" para los calzados 35 . Con todo, conviene recordar que la figura que estudiamos podría ser la beata Juana de Tolosa, la cual tiene también como atributo una cruz.

Vemos, de esta manera, que se han colocado en el retablo central junto a los tres personajes principales de la Orden: San Elías, San Eliseo y San Juan Bautista, a San Alberto, el legislador de la misma y, por tanto, el que hizo posible que esta existiera como tal. $Y$ a otros personajes importantes por sus cargos eclesiásticos y por defender la imagen de María como verdadera Madre de Dios. Ello muestra como los carmelitas siempre han querido resaltar la imagen de su Orden.

35 ANCILLI, E. (O.C.D.): "María Magdalena de Pazzi, santa” en SAGGI, L. (coord.): op. cit, págs. 393-418. 


\section{2: artículos La Flor del Carmelo. Iconografía y mensaje simbólico...}

Pasando a la atribución de la autoría de dicha imaginería seguimos a Romero Benítez ${ }^{36}$ para quién todas las esculturas del retablo es decir las imágenes de San Elías, San Eliseo, San Juan Bautista, los papas y obispos, son obra del escultor José de Medina. Señala la posibilidad de que sea él también el autor de los óvalos de las santas y de la Virgen y el Salvador situados en el banco del retablo, pues se asemejan a otras obras suyas del retablo lucentino que se ha mencionado. Los arcángeles muy parecidos a los del retablo de los Remedios de Estepa- se sabe con certeza que son de Diego Márquez, pues, en la restauración a que fueron sometidas todas las esculturas de este retablo en 1990, promovida por la Junta de Andalucía a través de la Dirección General de Bienes Culturales de la Consejería de Cultura y llevado a cabo por empresa "Arte y Ciencia", que consistió en, una vez desmontadas las piezas del retablo, fijar su policromía y someterlas a su desinsectación ; se pudo comprobar como la figura de uno de los arcángeles estaba firmada y fechada en su vacío posterior , a lápiz sobre madera y a tinta sobre un pequeño papel pegado con cola "Diego Márquez me fecit. Año 1755". Obras de esta magnitud, necesitarían numerosos colaboradores, y éste autor, al que se le atribuyen otras obras de importancia de esta iglesia, también trabajó con Medina en la realización de tan numerosa imaginería.

Pero el retablo central se encuentra acompañado por otros dos retablos laterales. Los tres colaboran entre sí para crear el espacio casi irreal de esta capilla mayor. El del lado del Evangelio esta dedicado a San Elías y el de la Epístola a un Ecce Homo o Cristo de las Penas. Al parecer fueron de realización más tardía especialmente el de la Epístola ya que su estilo es plenamente tardobarroco. Sin embargo, los dos llegaron a dorarse. Ambos se estructuran en tres niveles y tienen el cuerpo central dividido en tres calles separadas por estípites, asemejándose en esto, si bien a menor escala, a la estructura del retablo central.

\footnotetext{
36 ROMERO BENITEZ, J.: op. cit., pág. 96.
} 
